\title{
Greek borrowings in Russian literary text as value translators of helinistic and byzantine culture
}

\author{
Viktor Shaklein*, Anastasia Skomarovskaya, Svetlana Mikova \\ Peoples' Friendship University, 117198, Moscow, Russia
}

\begin{abstract}
Absctact. The article attempts to identify the stylistic functions of Greek origin vocabulary in Russian-language texts. The material of the study are selected works of the poet of the second quarter of the XIX century, Alexei Khomyakov as one of the founders of Russian philosophical thought and the Slavophil movement. The method of continuous sampling of the text selected Greekism, found in the poems of the author, regardless of the time of their penetration into the Russian language. Using contextual analysis revealed their expressive functions. Particular attention is paid to the cultural function of Greek vocabulary as a translator of Hellenistic and Byzantine cultures that have had a significant impact on Russian culture.
\end{abstract}

\section{Introduction}

Borrowed vocabulary, to one degree or another, bears the imprint of the native language, and hence the culture from which it came. In the conditions of the modern globalized world, the issues of the cultures' interaction acquire special relevance, in connection with which the number of linguoculturological studies devoted to the identification of cultural meanings in the language is growing. Our work has also been done as part of the linguoculturological paradigm.

Greek borrowings fell into the Russian language at different times, starting from the preliterate era thanks to the linguistic contacts of the ancient Greeks with Slavic tribes. In the works of modern sociolinguists, borrowing is mainly considered as the result of language contacts (Brian, 2015; Aikhenvald 2002; Clyne 2003; Haugen 1953; Matras 2009; SilvaCorvalán1994; Thomason 2001 and others). In our article, we pay attention not to the process of borrowing as a result of linguistic contact, but to the functioning of borrowing as a result of contacting in the Russian culture texts on the basis of the selected author works.

A study of the fiction language reveals not only the specific idiostyle of a particular writer, but also the features of the national language development in one or another period of its development: "Knowing the texts language, the researcher reveals the meaning of these texts and his role in the organization of individual and general language units, clarifies the nature conceptual systems implemented by the authors of the texts; these data can make up the bridge leading to the "language of the era" "(Shaklein, 2002). Thus, studying the features of

*Corresponding author: rakhlitska@mail.ru 
the language of the particular word artist works, we can come closer to understanding the features of the conceptosphere development for the national language at a certain period of its development.

\section{Research method}

The purpose of this article is to determine the functions of Greek origin vocabulary in the Russian literary text, as well as to identify the linguocultural potential of Greekisms in the Russian language. Greekisms were selected from poetic texts and their stylistic and cultural significance was revealed with the help of semantic and contextual analysis. For reference, we turned to the data of the Lexicographic Internet portal: online dictionaries of the Russian language (https://lexicography.online/).

Research on material from different languages and in different aspects is devoted to borrowings from the Greek language (see, for example, Dolgushina, 2016; Delijorgji, Foci, 2014 , etc.). The object of study in our article is Greek borrowings in the broad sense of the word, which include both direct borrowings of words and indirect ones - derivational and semantic tracing: "Loan words are lexical items in which all or part of the morphemic composition of the loan derives from the source language. Loanshifts are lexical items whose morphemic composition is entirely native and whose meaning derives at least in part from the source language "[Alvanoudi, 2018. P. 5]. What interests us is not the structure of words, but the expressive and cultural significance of Greekisms, which is realized in literary texts. Therefore, we deliberately distract from issues related to periods of borrowing from Greek, as well as with the method of borrowing, i.e. direct or through an intermediary language.

The material of the study was taken from the poetic texts of Alexei Khomyakov, one of the ideologists of the early Slavophilism, created in the second quarter of the XIXth century (http://ruspoeti.ru/aut/homyakov/). The significance of the Slavophiles' work, both journalistic and artistic, is unusually great in the sense that Russian philosophical thought originates from them. "The Slavophiles laid the foundations of the Russian national philosophical tradition, centered on the ideas of holistic knowledge, spirit and life, collegiality" (Kosharny, 2007. 519). The work of Slavophil poets is interesting in the context of turning to traditionalist concepts of building a society.

Most Slavophiles advocated the cleansing of the Russian language from borrowings. In this regard, the study of borrowings in the poetry of the Slavophile trend becomes especially significant. Let us prove that the Greeks are organically woven into the fabric of the Russian poetic text, moreover, a text with a claim to originality, like all the work of the Slavophiles.

A lot of research is devoted to the study of the words' stylistic functions in a literary text. For example, N.V. Kolesova identifies eight functions of borrowed words in the idiostyle of V. Aksenov (Kolesova, 2005). Modern European authors pay great attention to the pragmatic function of words (Andersen, 2014; Ilić, 2017). Here it must be emphasized that there is no invariant of stylistic functions that would fit all texts and tokens of different groups. It all depends on the specific idiostyle, as well as on the author's attitudes.

Since the material of our study is poetry, we focus on the expressiveness of their language.

Most modern researchers understand expressivity quite widely. Some expressiveness understand the spectrum of human emotional states (Moskvin, 2006). Others believe that expressiveness is the ability to arouse feelings, including through figurativeness - the ability of a verbal work to arouse images in the reader's soul, i.e. representations (Annushkin, 2014): a scientist associates expressivity with imagery.

If to summarize most of the works devoted to expressivity, we can distinguish several semantic bases on which this category is based:

1) the concept of assessment - "when the assessment manifests itself as a direct reaction to events" (Wolf, 2006); 
2) the concept of intensity - "as such a property of a text or part of a text that conveys meaning with increased intensity and results in emotional or logical reinforcement" (Arnold, 1990);

3) the concept of emotion (Moskvin, 2006).

\section{Findings}

By expressiveness in the broad sense of the word, we mean any deviation from the neutral mode of speech. Thus, what is non-standard, unusual, emotional is expressive. After analyzing the poetry texts of A. Khomyakov and taking into account the above aspects of the expressiveness study for a literary word, we offer our own classification of the expressive functions for Greekisms.

\section{Expressive function to create a sublime style effect}

Most of the Greek vocabulary in the poems of A. Khomyakov serves to create a high style. This is due to the fact that, on the topic of Greekism, which fell into the Russian language, belong to such thematic groups as poetry, science, mythology, religion, which, as a rule, implies a high connotation of the word. Context analysis also confirms our point.

He raised a calm gaze to the sky,

And to God, a hymn arose in the soul ... ("Poet")

"Hymn" from the Greek "laudatory song, praise and glorification, in verse or in music, chant" (https://lexicography.online/explanatory/dal/). The semantics of praise and glorification contained in this word create the effect of elation and solemnity. This connotation is also emphasized by the contextual environment of the word: the tokens "gaze" and "sky" belong to the same high register of speech.

\section{Expressive imaging function}

An image is the most important linguistic entity, which contains basic information about the relationship of a word with culture. Traditionally, imagery is understood as the ability of linguistic units to create visual-sensual representations of objects and phenomena of reality (Maslova, 2001).

When creating the image of a literary work by A.S. Khomyakov uses the figurative meaning of words, using borrowings from Greek, as a rule, direct. For example, we read:

... stars of thoughts drive

Secret choir around the earth ... ("Stars")

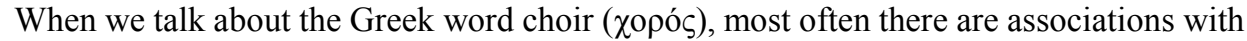
the choir of the Greek tragedy, which appeared in ancient times. The choir is from Greek.

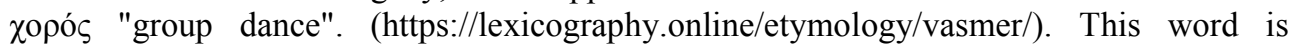
borrowed in the first third of the XVIIIth century from the Greek language, where choros originally means "group dance with singing" (https://lexicography.online/etymology/shansky/). Obviously, the author uses the word "choir" precisely in the meaning of "dance", which came from Greece. This is also indicated by the verb "lead," which refers to the choir as a dance. Interestingly, in the L.P. Krisin modern dictionary of foreign words is already fixed only the meaning of the word choir associated with singing. The dance value has been lost (https://megabook.ru/article/).

\section{Emotional evaluation function}


The late lampada was burning

Infront my sleepy laziness ... (1837)

The word "lampada" gives a melancholic tone to the whole poem. According to the dictionary V.I. Dalia, "Lampada <..> a night lamp in oil, <..> suspended on chains from icons" (https://lexicography.online/). The author uses the non-neutral word "lamp", which has already come into use since the time of Peter I (https://lexicography.online/etymology/vasmer/), or "lamp", he intentionally uses Greekism "lampada" to convey a certain emotional elegiac mood. In the context of the poem, it helps to convey the author's evaluative attitude. "Lampada" is usually accompanied by an icon. In this poem, the rays of the lamp are lighting a girl who inspires the poet to create his works. Thus, an emotional-evaluative attitude arises to poetic work as a sacred act.

On the other hand, the word "lampada" also performs a figurative function, giving rise to a metaphor for the poet's sleepy, as it were smoldering life in the absence of inspiration. "Late lampada", "sleepy laziness" are replaced by "pure flame of art" after the appearance of a bright image of the heroine.

Borrowed vocabulary always bears the imprint of the original culture. In this regard, it carries out a linguoculturological function in the text, the essence of which is the translation of cultural meanings. This is a kind of "overfunction", which is implicitly present, to a greater or lesser extent manifested in different texts containing borrowings, and also incorporates an expressive function. In the poems we are studying, we have identified two private cultural functions of borrowed Greekisms, which historically correlate with two periods of Greek culture, which have had a greater impact on Russian culture.

\section{Retrospection into the culture of Hellenism}

In many works of A.S. Khomyakov refers to Hellenistic culture as exemplary. In the poem "The Epistle to the Venevitins", the poet addresses many of the precedent phenomena of Ancient Greece, depicting the ideal organization of an ancient state based on freedom and democracy. Speaking about the past of the country with high pathetics, the author uses Greekism "Hellas", as if sending us back, through the centuries, to the highest culture. The Greek anthroponyms "Demosthenes", "Zeus", "Leonid", "Mnemosyne”, "Phoebe", "Parnas", toponym "Thermopylae", nominations "muses", "anthem", "lyre" are used in the poem. Onomastic vocabulary not only calls the realities of Ancient Greece, but also denotes objects that are understandable to everyone, which are, as it were, a common European heritage. Similar tokens are included in the linguocultural field "Hellenistic culture" in the Russian language. The linguistic units that make up this field have a positive assessment, naming everything significant that was created in ancient culture. This is philosophy, art, heroism and patriotism - all the best that Ancient Greece created and what other peoples are equal to. The poet calls ancient Hellas "a country of great affairs," which, however, for a long time "moaned under the yoke," from which it was time to free itself.

Thus, in the poems there is a linguistic-cultural field "Hellenistic culture", formed by the semantics and connotations of lexemes of Greek origin, as well as their contextual environment.

\section{Transfer of Orthodox Byzantine culture}

The widest linguistic and cultural field represented by the Greeks in the poetry of A.S. Khomyakov, correlates with one of the provisions of the Slavophiles doctrine, namely with Orthodoxy. These are direct borrowings: icon, lampada, cross, chrism, incense, angel, Satan, God; as well as derivational tracing papers with a Greek basis. Among them are words with 
an element of god-and all-: savor, Almighty, godless. Often there are semantic tracing papers. For example, in an untitled poem of 1844 :

Do not say: "That old,

Either antiquity, then the sin of the fathers ...

The word "sin" belongs to the Slavonic vocabulary and has the original meaning "error, mistake", or to sin (against the truth), flaws. It is a sin of the same root to warm the verb (the word is formed using the suffix according to the same model as laughter). Originally, sin meant "what burns, torments." With a religious meaning, this word begins to be used from the time of the Old Slavonic language (https://lexicography.online/etymology/) in translated Greek texts. Thus, under the influence of Byzantine religious semantics, the meaning of the original word is reinterpreted in the language.

Such widespread use of Greekisms belonging to the linguistic-cultural field "Orthodoxy" can be explained by the ideology of the Slavophiles. Philosopher N.A. Berdyaev noted that "the ideal sprouts of Christianity in the Russian soul can be studied by Slavophilism" (Quoted in Kolesov, 2006: 276).

\section{Conclusion}

Thus, in the texts of poems by A.S. Khomyakov Greek borrowings are quite widely used. Despite the general attitude of the Slavophiles to consciously avoid borrowed vocabulary, we were convinced that Greekisms are often used to create expressiveness of the text. This is due to the emotional-evaluative component present in the seminal structure of loan words, as well as due to the widespread use of Greekisms to create an artistic image of the poem.

Obviously, Greek culture had a powerful influence on the development of Russian society, which was widely reflected in the language. Byzantine culture brought especially many concepts, which is confirmed by a large number of borrowings associated with the powerful field "Orthodoxy", which can perform all kinds of functions in the text. Greekisms have become an organic part of the lexical system of the Russian language, denoting Greek concepts that have become native to Russian culture. At the same time, borrowed vocabulary bears the imprint of a culture - a donor. This can be detected at the level of word concepts, as well as at the level of functioning of words in the text, which provides wide material for further research.

We were convinced that Greekisms in poetic texts can fulfill expressive meaning, and at the same time they always bear the imprint of Greek culture, which had a huge impact on Russian linguistic culture.

The publication has been prepared with the support of the "RUDN University Program 5-100"

\section{References}

1. J. Zh. Varbot, A.F. Zhuravlev, A brief conceptual and terminological guide to etymology and historical lexicology (Russian Academy of Sciences, Institute of the Russian Language VV Vinogradova RAS, Etymology and history of the words of the Russian language, 1998).

2. A.Y. Aikhenvald, Language Contact in Amazonia (Oxford University Press, Oxford, 2002).

3. V.I. Annushkin, Communicative qualities of speech in the Russian phraseological tradition (Flint, Nauka, 2014).

4. I.V. Arnold, Stylistics of the modern English language (Education, Moscow, 1990). 
5. Biljana Mišić Ilić, Pragmatic borrowing from English into Serbian: Linguistic and sociocultural aspects, Journal of Pragmatics, 113, 103-115. 2017, Information on https://doi.org/10.1016/j.pragma.2017.01.010

6. Brian D.Joseph, Language Contact, International Encyclopedia of the Social \& Behavioral Sciences (Second Edition), The Ohio State University, Columbus, OH, USA.2015, 300-306. Information on https://doi.org/10.1016/B978-0-08-0970868.53016-5

7. M. Clyne, Dynamics of Language Contact: English and Immigrant Languages (Cambridge University Press, Cambridge, 2003).

8. S. Delijordji, I. Foci, The paradigmatic group of the borrowings in the modern Albanian language form Greek, Mediterranean Journal of Social Sciences, 5 (27), 1628-1631 (2014).

9. L.V. Dolgushina, Some features of early Slavic translations from Greek (on the material of the collection thirteen homilies of St. Gregory of Nazianzus, Vestnik Tomskogo Gosudarstvennogo Universiteta, Filologiya, 42 (4), 5-11.

10. Gisle Andersen, Pragmatic borrowing, Journal of Pragmatics, 67, 17-33 Information on https://doi.org/10.1016/j.pragma.2014.03.005

11. E. Haugen, The Norwegian Language in America: A Study in Bilingual Behavior (IndianaUP, Bloomington, 1953).

12. V.V. Kolesov, Russian mentality in language and text (Petersburg Oriental Studies, St. Petersburg, 2006).

13. L.V. Kolesova, Borrowings in the idiostyle of V. Aksenov, Abstract. for the competition step. Cand. filol. sciences. Krasnoyarsk, 2005.

14. V.P. Kosharny, A.S. Khomyakov, Creative heritage of A.S. Khomyakova and the phenomenon of national philosophy, thinker, poet, publicist: collection of articles (Mosocw, 2007) 1.

15. O.D. Kurakina, A.S. Khomyakov, The founder of the original Russian philosophy, Thinker, poet, publicist: collection of articles (Mosocw, 2007) 1.

16. Language contact, borrowing and code switching, A case study of Australian Greek. Journal of Greek Linguistics, 18, 3-44 (2018).

17. V.A. Maslova, Linguoculturology. Workbook for students of higher educational institutions (Moscow, 2001).

18. Y. Matras, Language Contact (Cambridge University Press, Cambridge, 2009).

19. V.P. Moskvin, Expressive means of modern Russian speech: Trails and figures. General and private classification, Terminological Dictionary Text (LENAND, Moscow, 2006).

20. E.F. Gubsky, Philosophical Encyclopedic Dictionary (FES, 2003).

21. V.M. Shaklein, To the methodology of linguocultural research of the text as a material for studying the linguocultural situation, Bulletin of RUDN University, ser. Linguistics, 3, 169-179 (2002).

22. M.A. Shirokova, Slavophiles as the founders of Russian national philosophy, News of Altai State University (2010). Information on https://cyberleninka.ru/article/n/slavyanofily-kak-osnovopolozhniki-russkoynatsionalnoy-filosofii

23. C. Silva-Corvalán, Language Contact and Change: Spanish in Los Angeles (Clarendon Press, Oxford, 1994). 
24. S. Thomason, Language Contact: An Introduction (Edinburgh University Press, Edinburgh, 2001).

25. E. M. Wolf, Functional evaluation semantics (URSS editorial, Mosocw, 2006).

26. Information on http://ruspoeti.ru/aut/homyakov/

27. Information on https://lexicography.online/

28. Information on https://lexicography.online/etymology/

29. Information on https://megabook.ru/article/ 